\title{
Planktivory in non-indigenous fish and implications for trophic interactions in a Mediterranean shallow lake
}

\author{
Bruno B. Castro ${ }^{1 *}$ and Fernando Gonçalves ${ }^{1}$ \\ ${ }^{1}$ Department of Biology and Centre for Marine and Environmental Research (CESAM), University of Aveiro, \\ 3810-193 Aveiro, Portugal
}

Received 4 October 2010; Accepted 18 April 2011

\begin{abstract}
Similar to other Mediterranean lakes, Lake Vela displays a marked dominance of alien species, but the impact of such an assemblage on the lower trophic levels of shallow eutrophic lakes has been overlooked. In this study, zooplanktivory in the omnivorous fish assemblage of Lake Vela was examined from April to October 2003 (and also in January 2004). During this period, ichthyocenosis was characterized by abundance of juvenile fish, which strongly depended on zooplankton. Adult mosquitofish (Gambusia holbrooki) and pumpkinseed (Lepomis gibbosus) foraged on the same zooplanktonic prey than juveniles, although planktivory was less important in larger fish. Using multivariate analysis, it was possible to attribute most of the variability in planktivory to resource availability, as both fish foraged on the most abundant prey in each month. Albeit this opportunistic behaviour, mosquitofish was found to be positively selective towards small-sized littoral cladocerans, while pumpkinseed displayed positive selection towards Alona and Daphnia. In the absence of more efficient planktivores, pumpkinseed is now the main planktivore in Lake Vela and the main predator of Daphnia. However, due to low densities of Daphnia during most of the study period, Daphnia was virtually absent from the diet of pumpkinseed from June to October, a period during which this benthi-planktivore foraged chiefly on less-rewarding planktonic prey (small-sized cladocerans and cyclopoid copepods). Mosquitofish was an important planktivore in littoral and structured habitats. Flexible foraging behaviour partly explains the success of these two species in Lake Vela.
\end{abstract}

Key words: Zooplanktivory / alien fish / Gambusia holbrooki / Lepomis gibbosus / Mediterranean shallow lake

\section{Introduction}

Fish play a key role in the trophic dynamics and ecosystem functioning of lakes. Through predation on zooplankton, planktivorous fish may promote increased phytoplankton biomass and reduced water clarity (Scheffer, 1998; Castro and Gonçalves, 2007). The importance of planktivory in freshwater ecosystems is well illustrated by the structuring role of planktivores in trophic cascading phenomena (e.g., Williams and Moss, 2003; Tátrai et al., 2003; Blanco et al., 2004), especially young-of-the-year (YOY) fish (Post et al., 1997; Romare et al., 1999; Hansson et al., 2007). This structuring role has been studied in detail in northern temperate lakes (see e.g., Romare et al., 1999; Eklöv and VanKooten, 2001; Romare and Hansson, 2003). However, several authors (e.g., Beklioglu et al., 2007; Teixeira de Mello et al., 2009) argue that the cascading effects of planktivorous fish are

\footnotetext{
*Corresponding author: brunocastro@ua.pt
}

much more pronounced in warmer (subtropical and Mediterranean) and shallower lakes (Jeppesen et al., 1997, 2007). This is due to the predominance of an omnivorousbased fish community with very high biomass, dominated by small-sized species with multiple spawns, and to the low abundance of efficient piscivores (Blanco et al., 2003; Beklioglu et al., 2007; Teixeira de Mello et al., 2009). Such small-sized omnivores prey heavily on zooplankton, suppressing large-sized herbivores (like Daphnia) for long periods in shallow lakes, thus preventing the control of phytoplankton growth (Beklioglu et al., 2007). Thus, warm shallow lakes face a fish-induced trophic cascade that promotes the occurrence and permanence of an algaldominated and turbid condition.

This latitudinal fish community structure paradigm has attracted attention as an explanation for the evidence that lakes from warmer regions are more vulnerable to nutrient loading (i.e., eutrophication) and less susceptible to biomanipulation (see Moss et al., 2004; Romo et al., 2004; Jeppesen et al., 2007). Also, some authors (Teixeira 
de Mello et al., 2009; Jeppesen et al., 2010) predict that climate warming will cause or intensify eutrophication effects via alterations in the fish community structure in the temperate zone. Another global threat to fish communities and aquatic ecosystems is the invasion by non-native fish (Cambray, 2003; Ruesink, 2005). Given the structuring role of fish in freshwater food webs (see above), the potential disruption of trophic webs by alien fish and its cascading effects on lower trophic levels should be viewed as a serious environmental problem. Also, Ruesink (2005) alerts that the establishment success of aliens is higher for fishes in families with small body size and for omnivores. Omnivory is the maximum expression of phenotypic plasticity in the exploitation of resources (detritus, benthic fauna and zooplankton), allowing predators to explore diverse food resources without compromising growth and mortality rates - flexible foraging behaviour (Roseman et al., 1996; Scheuerell et al., 2005).

Blanco et al. (2003) suggest that fish communities of tropical and Iberian lakes share common features, such as a high degree of omnivory, lack of piscivores and predominance of small-sized species. Such features are particularly exacerbated by the vulnerability of the Iberian fish fauna to opportunistic invaders (Almaça, 1995), such as pumpkinseed sunfish (Lepomis gibbosus) or mosquitofish (Gambusia holbrooki). These small-bodied and fecund fish have become very successful invaders in Iberian lentic systems (Almaça, 1995), foraging on a broad range of food items, including zooplankton (García-Berthou, 1999; García-Berthou and Moreno-Amich, 2000). These two species constitute the main fish species in terms of abundance in Lake Vela (Portugal), a polymictic shallow lake, highly eutrophic (Castro and Gonçalves, 2007), which displays a poorly diversified fish community. A large fish kill at the end of May 2001 illustrated the cascading effects of its fish community, causing an abnormal Daphnia-dominance phase in Lake Vela during the whole summer, which resulted in an effective control of summer phytoplankton (Antunes et al., 2003; Abrantes et al., 2006). However, in most occasions, Lake Vela is highly turbid (Castro and Gonçalves, 2007).

Taking into account the structuring role of fish, it is vital to possess a comprehensive view on the ecology of the fish community and its trophic interactions. This is particularly important in warm temperate lakes, which face serious threats from climate warming, eutrophication and alien species invasion. Bearing this in mind, we conducted a detailed analysis on the planktivory of the main fish species from Lake Vela, a Mediterranean polymictic lake (see Castro and Gonçalves, 2007), whose fish community is dominated by non-native species (mostly pumpkinseed, mosquitofish, largemouth bass (Micropterus salmoides) and carp (Cyprinus carpio)). The main goals of the study were: (1) to identify the main sources of variation (ontogeny vs. resource availability) in the diet of the main planktivores and (2) to assess the relative importance of the main zooplanktonic taxa in the diet and to detect patterns of prey selection (electivity).

\section{Materials and methods}

\section{Fish sampling and gut content analysis}

Fish were collected monthly from April to October 2003 as a pooled sample from two different sampling locations in Lake Vela. In order to make our dataset more comprehensive, we also captured fish later in January (winter). A combination of seine nets and electrofishing (using portable gear and dip nets) was used, covering both open-water and vegetated areas, with a constant sampling effort (15 min electrofishing and 2-3 net hawls at each site). The joint use of such methods underestimates large evasive fish, but it is particularly useful in collecting smaller specimens (including new recruits), especially in structured environments (near the shore and in macrophyte beds). All captured fish were sorted by taxon and immediately stored on ice and later frozen.

In the laboratory, all individuals were counted after thawing, and length measurements (total length, TL) were performed with a precision of $0.5 \mathrm{~mm}$. An initial subsample of 50 specimens (or all, if $n<50$ ), comprehending all possible size classes for each combination of month and species, was selected for gut content inspection. These specimens were eviscerated and non-empty stomachs were preserved in $70 \%$ ethanol, until further processing was possible. Since mosquitofish lack a distinctive and individualized stomach, the anterior third of the gut was excised (Cabral et al., 1998). Enumeration of gut contents was only carried out on non-empty stomachs in which most food categories could be clearly identified (proportion of digested material $<50 \%$ total stomach content volume) to minimize bias due to differential digestion of prey items (Hyslop, 1980; Amundsen et al., 1996). A total of 25 stomachs per month were analysed on average $( \pm \mathrm{SD})$ for mosquitofish $(n=24.4 \pm 1.8)$ and pumpkinseed $(n=25.1 \pm 2.5)$. Gut contents were sorted to genus or family level and counted, under a dissecting microscope. If necessary, subsampling was used for abundant contents. Volume of the total zooplankton (pooling all taxa) relative to total stomach content volume was visually estimated.

\section{Zooplankton sampling}

Zooplankton was sampled fortnightly from April 2003 to January 2004 as a pooled composite sample from two different sampling points in Lake Vela: a vegetation-free site and near a macrophyte (Nymphaea alba) patch. Composite water samples were collected at each site with a vertical Van Dorn bottle (sample volume: 16-25.6 litres) and concentrated with a $55-\mu \mathrm{m}$-mesh plankton net. Each sample was immediately preserved in sucrose-saturated $4 \%$ formalin, stained with Bengal rose, and stored until further examination. In the laboratory, cladocerans were identified to the genus/species level and copepods were separated into nauplii and copepodites + adults (cyclopoid or calanoid). Counting by subsampling was used for the most abundant taxa, but the whole sample was usually 
screened in order to enumerate large organisms (particularly Daphnia). Zooplankton abundance data were expressed in density (ind. $\mathrm{L}^{-1}$ ).

\section{Diet analysis}

Prey-specific abundance (sensu Amundsen et al., 1996) and frequency of occurrence (FO) were used to estimate the dietary importance of each food category. For prey $i$, prey-specific abundance $(\%)$ is the number of individuals of prey $i$ divided by the total number of all prey items in consumers who have ingested prey $i$. Correspondingly, FO corresponds to the proportion of stomachs containing prey $i$ (relative to the total number of examined stomachs). These parameters were used to describe feeding strategy for each fish species using the graphical method of Amundsen et al. (1996).

Correlation was used to assess the relationship between zooplankton ingestion and fish size (Pearson's $r$ was used for abundance data, while Spearman's $r_{\mathrm{s}}$ was utilized for percent volume). Log transformation of data was used when this improved linearity.

The preferences of fish for different zooplankton species were estimated for each predator and prey item using Vanderploeg and Scavia's relativized electivity index $\left(E^{*}\right)$, following Lechowicz (1982):

$$
E_{i}^{*}=\frac{W_{i}-(1 / n)}{W_{i}+(1 / n)}, \quad \text { with } W_{i}=\frac{r_{i} / p_{i}}{\sum r_{i} / p_{i}},
$$

where $r_{i}$ is the percent share (proportional abundance) of prey $i$ in the diet, $p_{i}$ is the percent share of prey $i$ in the environment and $n$ is the number of prey types included in the analysis. The index ranges from -1 (negative selection) to 1 (positive selection), with values close to zero indicating neutral selectivity (see also Lechowicz, 1982; Gliwicz et al., 2004; Alcaraz and Garcia-Berthou, 2006). Spearman correlation coefficient $\left(r_{\mathrm{s}}\right)$ was used to assess the relationship between electivity and fish size (TL). To test whether electivity significantly deviated from 0 (i.e., neutral selection), a one-sample sign test was applied to the most important prey taxa. The use of this simple non-parametric method was justified by the non-normal and/or highly skewed distribution of the data. A significance level $(\alpha)$ of 0.05 was used.

\section{Multivariate analysis}

Detrended correspondence analysis (DCA) was applied to log-transformed prey abundance data (excluding rare food categories) in order to describe the main sources of diet variation, using each fish (stomach) as a sampling unit. This family of multivariate techniques is often used in the analysis of dietary data (Godinho et al., 1997; GarcíaBerthou, 1999; García-Berthou and Moreno-Amich, 2000). The purpose of DCA is to reduce a species (food category) $\times$ sample (fish) matrix to a few dimensions (the eigenvectors) that explain the highest proportion of total variation in the data, without a priori pooling food categories, size classes or explanatory factors. Ordination axes were interpreted in terms of the potential sources of variation of the samples (species, sampling month and age class), by analysing the sample (fish) scores with nested analysis of variance (ANOVA; size class as the nested factor) or analysis of covariance (ANCOVA; using log fish length as the covariate).

Canonical correspondence analysis (CCA; ter Braak, 1986) was also used to examine the main sources of diet variation in each fish species. Two environmental matrices were taken into account as potential sources of variation in planktivory: (1) a resource matrix, comprising the densities of the zooplanktonic taxa recorded in the lake and (2) a (log) fish size matrix. The statistical significance of the model was tested using a Monte-Carlo (unrestricted) permutation test. A CCA-derived variation partitioning technique (Borcard et al., 1992; Økland and Eilersten, 1994) was used to quantify the variation explained by resource availability and fish size. This was performed by partialling out (as covariables - see ter Braak, 1988) each of the subsets of explanatory variables at a time and comparing the percentage of variance explained by the partial CCAs with the one obtained with the global CCA model (resource availability + fish size).

\section{Results}

The fish community of Lake Vela was dominated in numbers by pumpkinseed sunfish, mosquitofish and largemouth bass. Carp and sand smelt (Atherina boyeri) were also occasionally found. We will focus on the diets of the first two alien species, which displayed a high degree of planktivory (see Fig. 1) throughout the year - see supplementary material. Non-zooplanktonic prey of both species consisted mainly of benthic invertebrates, particularly diptera larvae (Fig. 1), whose importance increased with fish size. Although dietary data for largemouth bass will not be analysed, it is important to point out that a high degree of planktivory was also observed in YOY bass ( $\mathrm{TL}<50 \mathrm{~mm}$ ), in May and June (see Appendix).

\section{Dietary variation}

As a whole (pooling all zooplanktonic taxa), zooplankton was the most important food category (see Fig. 1) for mosquitofish $(\% \mathrm{O}>50 \%$, except in August $)$ and pumpkinseed ( $\% \mathrm{O}>67 \%$, except in August). Zooplankton consumption in August was much less important than in the rest of the year. There was substantial seasonal variation in the proportion of each zooplanktonic species consumed - see supplementary material. Also, the use of zooplankton in the diet of both species varied significantly with size (Fig. 2). Smaller-sized pumpkinseeds were more dependent on zooplankton than larger specimens. Large mosquitofish ate more zooplankton (in numbers) than smaller specimens, but the relative contribution (volume) 


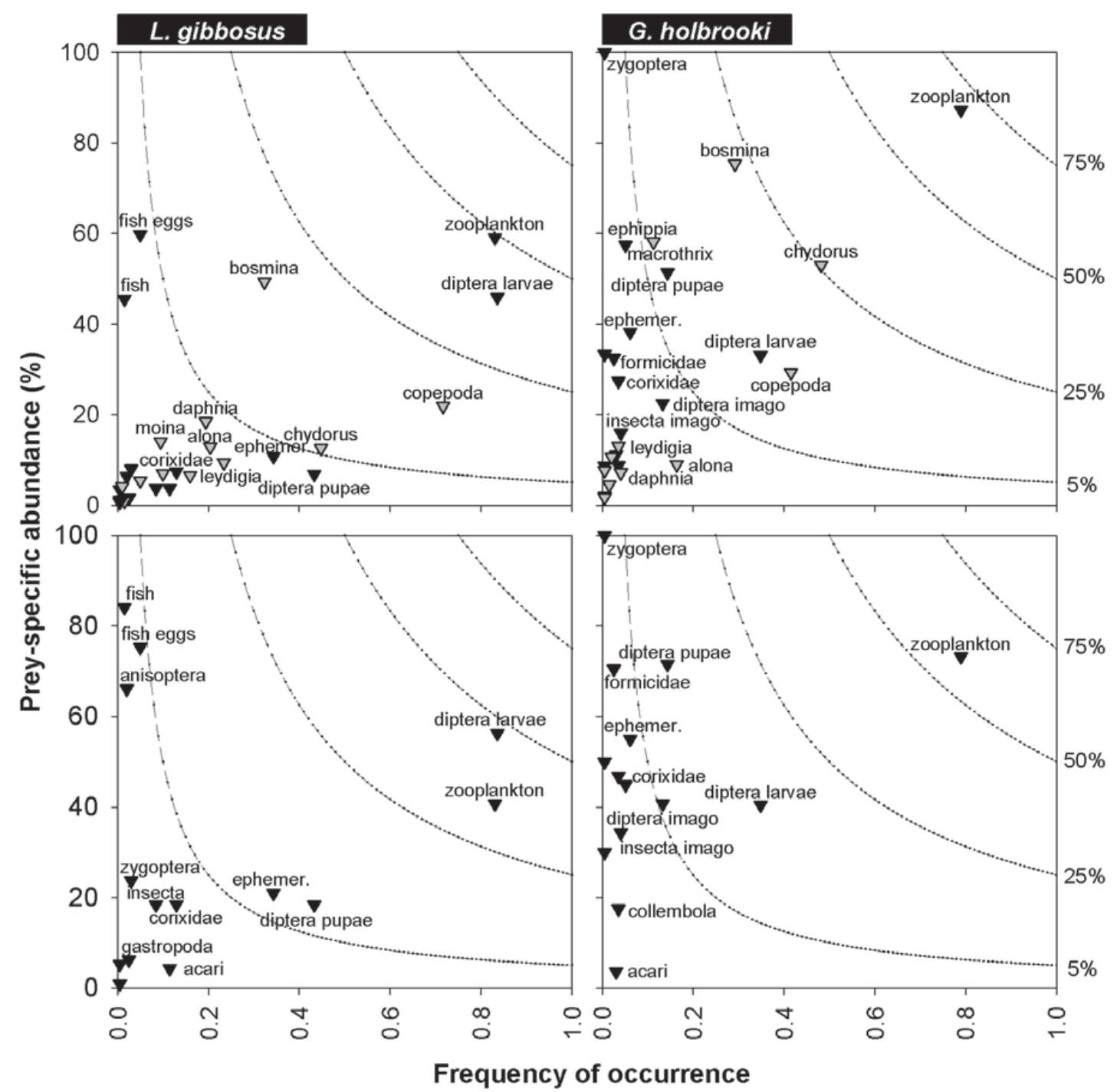

Fig. 1. Feeding strategy diagrams for L. gibbosus $(n=201)$ and $G$. holbrooki $(n=195)$ showing the importance of zooplanktivory. Microinvertebrates are depicted both as individual taxa (grey triangles) and as a pooled food category (zooplankton). Curves represent isolines (5-75\%) of prey volume or abundance (see Amundsen et al., 1996).

of zooplankton to the diet decreased slightly with ontogeny (Fig. 2).

Both the seasonal and ontogenetic components of pumpkinseed and mosquitofish diet were analysed after reducing the data matrix (two species, several size classes and eight sampling times) to its eigenvectors, using DCA (eigenvalues: axis $1=0.611$; axis $2=0.384$; total $=2.87$ ). For mosquitofish, significant differences between sampling months were found for fish scores of the first (ANCOVA: $F=59.4$; d.f. $=7,145 ; P<0.001$ ) and second (ANCOVA: $F=24.5 ;$ d.f. $=7,145 ; P<0.001)$ ordination axes. Fish length (covariate) did not contribute significantly to dietary variation (axis $1: F=1.88$; d.f. $=1,145 ; P=0.173$; axis $2: F=1.98$; d.f. $=1,145 ; P=0.162$ ). Seasonal variation was also significant in pumpkinseed diet (axis 1: $F=61.0$; d.f. $=7,157 ; P<0.001$; axis $2: F=36.2$; d.f. $=7$, 157; $P<0.001$ ), but fish size also contributed significantly for the ordination of fish scores in the first axis (axis $1: F=49.5 ;$ d.f. $=1,157 ; P<0.001$; axis $2: F=0.21$; d.f. $=1,157 ; P=0.648)$.

Plots of fish scores per month showed large seasonal fluctuations in resource exploitation (Fig. 3). For example, Daphnia consumption by pumpkinseed was only important in April and January, while Alona was a relevant prey in May; Macrothrix was an important food item for mosquitofish in September. A monthly analysis (Fig. 3 and Table 1) showed significant differences in resource use (nested ANOVA on DCA fish scores, using size class as the nested factor) between species in April-May (axis 1), June, July and January (axes 1 and 2). These differences were mainly due to the more frequent and abundant use of littoral prey (mostly Chydorus and Macrothrix) by mosquitofish, and the importance of Daphnia in pumpkinseed diet in April and January. Fish size (size class) was overall unimportant, except in a few cases (Table 1). The most noticeable example was the use of Daphnia by larger 


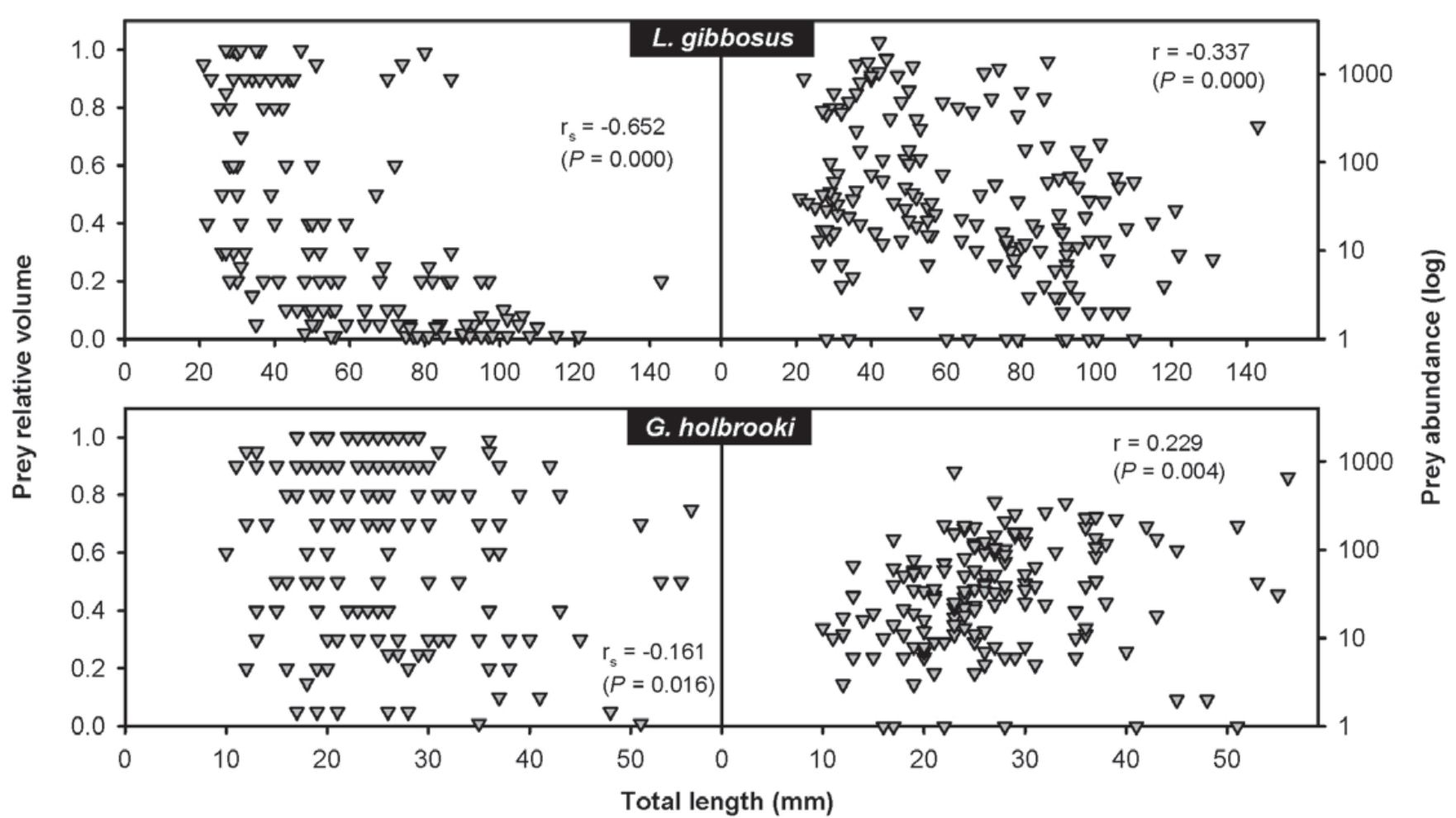

Fig. 2. Ontogenetic variation in planktivory (pooling all zooplankton taxa) of pumpkinseed (L. gibbosus) and mosquitofish (G. holbrooki).

pumpkinseed (TL $>60 \mathrm{~mm}$ ) in April (Fig. 3), in contrast to smaller specimens, which foraged chiefly on cyclopoid copepods and other cladocerans.

\section{Resource availability}

Overall, planktivory was mainly focused on the most abundant prey available (Fig. 4), mostly small-sized cladocerans (mainly Bosmina longirostris, Chydorus spp., Alona spp., Moina micrura and Macrothrix sp.) and cyclopoid copepods. A significant CCA model of fish scores (two species, eight sampling months), constrained by a resource matrix (zooplanktonic prey density in the lake), revealed that resource availability explained $35.4 \%$ (1.018) of the total variability (2.873). For pumpkinseed alone, zooplankton density in Lake Vela and fish size together explained $55.3 \%$ of the total variation (total inertia 2.056) in planktivory (CCA: Monte-Carlo test, $P<0.05)$. Using partial CCAs, we estimated the contribution of zooplankton density (resource availability) and fish size to be $49.7 \%$ (sum of all canonical eigenvalues $=1.021$ ) and $1.9 \%$ (sum of all canonical eigenvalues $=0.039$ ), respectively. Both models were significant (Monte-Carlo test, $P<0.05)$ and the remaining portion of variation $(3.7 \%)$ resulted from the intersection of both sets of explanatory variables. Similar results were found for mosquitofish: zooplankton density and fish size together explained $39.8 \%$ of the total variation (total inertia 3.573) of planktivory (CCA: Monte-Carlo test, $P<0.05$ ), with the larger portion of variance being explained by resource availability (38.7\%). The contribution of mosquitofish size to the total inertia (sum of all canonical eigenvalues = 0.013) was non-significant (partial CCA: Monte Carlo test, $P>0.05)$.

\section{Prey selection (electivity)}

When prey items were present in the lake, but were not found in stomachs (for some reason), electivity was equal to -1 . The absence of prey categories in the diet had a large influence in mean electivity index, resulting in negative selection for all zooplankton taxa (Fig. 5, white bars). A substantially different pattern was produced when all individual fish data points of value -1 (prey category absent in diet) were discarded (Fig. 5, grey bars). Either way, electivity was found to be independent of fish size, for all prey-planktivore combinations (Spearman correlation, $P>0.05)$. This allowed pooling all size classes. In this way, neutral selection (sign test, $P>0.05 ; H_{0}: E_{i}^{*}=0$ ) was found for most prey categories (Fig. 5), after excluding -1 data points. However, pumpkinseed was found to be positively selective (sign test, $P<0.05$ ) for Alona and Daphnia, while mosquitofish displayed significant positive selection for Alona, Chydorus and Macrothrix.

\section{Discussion}

Although more important in the diet of smaller specimens, zooplanktivory was substantial in all life stages 


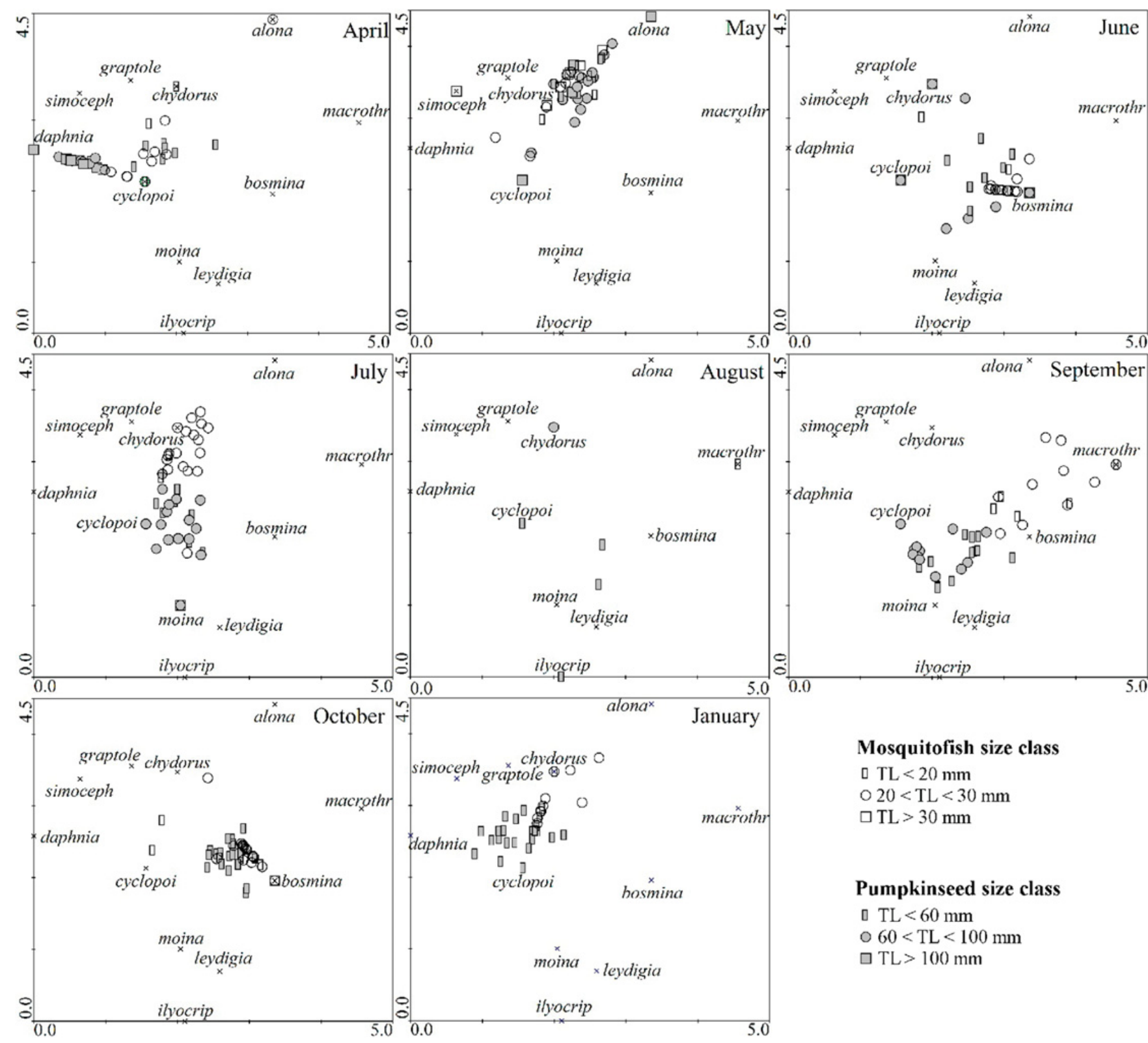

Fig. 3. DCA biplots of prey (cross) and fish scores (all other symbols) per month. Ordination axes eigenvalues stand for $21.3 \%$ (axis 1 ) and $13.4 \%$ (axis 2 ) of the total inertia (2.87).

of pumpkinseed and mosquitofish. Altogether, these two successful invaders are currently the main planktivores in Lake Vela, strongly relying on zooplankton as a food resource and thus exerting strong predatory pressure, especially given their high numbers. For example, we estimated a mean annual catch per unit effort (CPUE) of $130 \mathrm{~kg} \cdot \mathrm{ha}^{-1}$ (with a maximum of $300 \mathrm{~kg} \cdot \mathrm{ha}^{-1}$ ) for pumpkinseed alone, mostly YOY fish. This is a high biomass for a single species in a lake, close to the values observed in very shallow systems (Jeppesen et al., 1997).

Both mosquitofish and pumpkinseed displayed large fluctuations in the use of zooplanktonic taxa as prey, mostly due to seasonality (inter-month differences). A large portion of variation in the use of zooplankton in pumpkinseed and mosquitofish diet was explained by the resource matrix alone (zooplankton abundance in the environment). Still, a large fraction of variation remained unexplained, which could be attributable to random variation among individuals or other unknown factors. In both diets (mosquitofish and pumpkinseed), the strong dependence on resource availability confirmed these taxa as opportunistic feeders, foraging on the most frequent and abundant item in the zooplankton. Thus, seasonal variation in planktivory was mostly a reflex of the availability of prey in the environment.

Although the use of zooplankton (as a whole) in the diet was found to decrease with fish length, the use of zooplanktonic taxa was shown to be little dependent on fish size. No substantial ontogenetic shifts were found in either mosquitofish or pumpkinseed, although the latter 
Table 1. Nested ANOVA summary table applied to DCA sample scores (axes 1 and 2) in each sampling month. Main factor (species) has two levels: mosquitofish and pumpkinseed; nested factor (size class) has three levels in each fish species. All factors are considered fixed (i.e., non-random). Values in bold highlight statistically significant differences $(P<0.05)$.

\begin{tabular}{|c|c|c|c|c|c|c|c|}
\hline & Source of & & DCA axis & & & DCA axi & \\
\hline & variation & $\overline{\text { d.f. }}$ & MS & $P$ & d.f. & MS & $P$ \\
\hline April & Species & 1 & $5.0 \times 10^{8}$ & $<0.001$ & 1 & $2.0 \times 10^{3}$ & 0.991 \\
\hline & Size class & 4 & $4.3 \times 10^{8}$ & $<0.001$ & 4 & $1.6 \times 10^{7}$ & 0.386 \\
\hline & Residual & 40 & $1.8 \times 10^{7}$ & & 40 & $1.5 \times 10^{7}$ & \\
\hline May & Species & 1 & $1.3 \times 10^{8}$ & 0.019 & 1 & $2.3 \times 10^{6}$ & 0.715 \\
\hline & Size class & 4 & $7.4 \times 10^{6}$ & 0.856 & 4 & $1.1 \times 10^{7}$ & 0.631 \\
\hline & Residual & 40 & $2.2 \times 10^{7}$ & & 40 & $1.7 \times 10^{7}$ & \\
\hline June & Species & 1 & $4.1 \times 10^{8}$ & $<0.001$ & 1 & $7.6 \times 10^{7}$ & 0.047 \\
\hline & Size class & 4 & $3.8 \times 10^{7}$ & 0.165 & 4 & $2.1 \times 10^{7}$ & 0.351 \\
\hline & Residual & 37 & $2.2 \times 10^{7}$ & & 37 & $1.8 \times 10^{7}$ & \\
\hline July & Species & 1 & $4.0 \times 10^{6}$ & 0.382 & 1 & $8.7 \times 10^{6}$ & 0.469 \\
\hline & Size class & 3 & $1.4 \times 10^{6}$ & 0.842 & 3 & $1.6 \times 10^{8}$ & $<0.001$ \\
\hline & Residual & 43 & $5.2 \times 10^{6}$ & & 43 & $1.6 \times 10^{7}$ & \\
\hline August & Insufficient data & & & & & & \\
\hline September & Species & 1 & $2.6 \times 10^{9}$ & $<0.001$ & 1 & $9.1 \times 10^{8}$ & $<0.001$ \\
\hline & Size class & 2 & $6.4 \times 10^{7}$ & 0.109 & 2 & $1.4 \times 10^{7}$ & 0.255 \\
\hline & Residual & 41 & $2.7 \times 10^{7}$ & & 41 & $9.6 \times 10^{6}$ & \\
\hline October & Species & 1 & $3.4 \times 10^{6}$ & 0.487 & 1 & $5.5 \times 10^{5}$ & 0.760 \\
\hline & Size class & 2 & $8.8 \times 10^{7}$ & $<0.001$ & 2 & $9.6 \times 10^{6}$ & 0.205 \\
\hline & Residual & 43 & $6.9 \times 10^{6}$ & & 43 & $5.8 \times 10^{6}$ & \\
\hline January & Species & 1 & $1.3 \times 10^{8}$ & 0.015 & 1 & $8.2 \times 10^{7}$ & 0.006 \\
\hline & Size class & 2 & $5.8 \times 10^{6}$ & 0.739 & 2 & $1.3 \times 10^{7}$ & 0.263 \\
\hline & Residual & 34 & $1.9 \times 10^{7}$ & & 34 & $9.7 \times 10^{6}$ & \\
\hline
\end{tabular}

displayed some degree of heterogeneity in the use of some taxa (e.g., Daphnia) between larger and smaller specimens (see below).

Most literature on mosquitofish in Mediterranean countries (Cabral et al., 1998; García-Berthou, 1999; Margaritora et al., 2001; Blanco et al., 2004) has portrayed this species as being planktivorous, foraging chiefly on littoral microinvertebrates. This was also observed in the present study, where mosquitofish exhibited positive selection for littoral cladocerans, namely Alona, Chydorus and Macrothrix. Most planktivorous fish usually display a strong preference for larger prey (i.e., daphniids), but very few mosquitofish were found foraging on Daphnia or Simocephalus (littoral taxon). García-Berthou (1999) also found overall reduced importance of Daphnia in mosquitofish diet. Two complementary explanations are: (a) Daphnia is less abundant in the littoral micro-habitat occupied by mosquitofish and (b) most mosquitofish size classes are somewhat gape-limited relatively to large cladocerans. The coexistence of mosquitofish in mesocosms with large D. carinata (Matveev et al., 2000) seems to support the latter hypothesis.

Several studies (Hurlbert et al., 1972; Margaritora et al., 2001; Nagdali and Gupta, 2002) have shown that the impact of mosquitofish can be large, with its presence or absence producing distinct lake states (trophic cascade). However, these studies were conducted in ponds or artificial mesocosms, where mosquitofish was the only fish species present. In Lake Vela, as in many other shallow lakes, the small-sized mosquitofish competes with and is preyed upon by other fish species, which confine its occurrence to shallow channels, lake margins or sites with dense macrophyte coverage (Fernández-Delgado, 1989; Cabral and Marques, 1999; García-Berthou, 1999). However, the impact of mosquitofish on lake zooplankton is not unimportant, since its littoral foraging habits may nullify the refuge effect of macrophytes in predatoravoidance behaviour of zooplankton (Fernández-Delgado, 1989; Cabral and Marques, 1999; García-Berthou, 1999). Indeed, there is evidence of poor refuge effect of macrophytes in Lake Vela (Castro et al., 2007).

Planktivory in pumpkinseed was higher than what had been previously recorded outside of its natural range of occurrence (Godinho et al., 1997; Wolfram-Wais et al., 1999; García-Berthou and Moreno-Amich, 2000). Pumpkinseed is usually viewed as a benthic feeder, foraging on macroinvertebrates (Robinson et al., 1993). Although frequent, zooplanktivory usually is not very significant, except in the smallest specimens (Godinho et al., 1997; García-Berthou and Moreno-Amich, 2000; Maazouzi et al., 2010). However, Robinson et al. (1993) showed that the degree of zooplanktivory increases in the absence of more efficient zooplanktivores, such as bluegill sunfish or roach (see also discussion by García-Berthou and Moreno-Amich, 2000).

Pumpkinseed was the only fish species to forage extensively on Daphnia longispina, a key taxon in controlling phytoplankton growth and water transparency in Lake Vela (Antunes et al., 2003; Abrantes et al., 2006; Castro and Gonçalves, 2007). Substantial Daphnia consumption was limited to April and January, when daphniids were abundant $\left(>100\right.$ ind. $\mathrm{L}^{-1}$ ); during this period, pumpkinseed exhibited positive selection for D. longispina in Lake Vela, along with Alona spp. This 


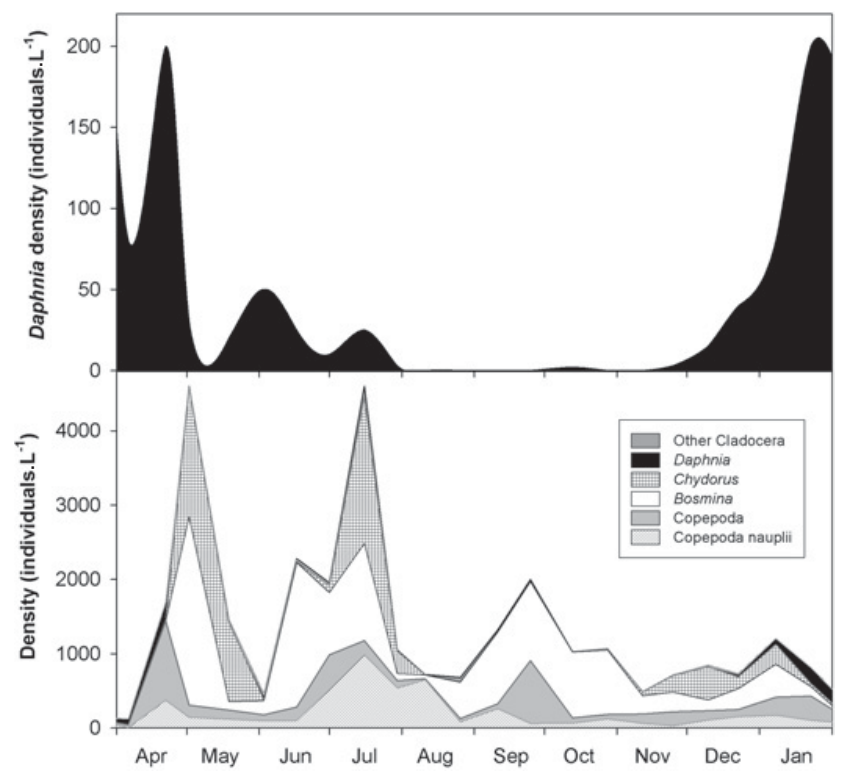

Fig. 4. Seasonal variation in the relative contribution (abundance) of the main zooplanktonic taxa (with emphasis on Daphnia - top panel) of Lake Vela during the fish sampling campaign. Note the different scales in YY axes.

supports the findings of García-Berthou and MorenoAmich (2000) that large cladocerans (such as Daphnia) are the preferred zooplankton prey of pumpkinseed. Our results have shown that predation on Daphnia was not restricted to YOY fish and that larger pumpkinseeds foraged more intensely on Daphnia than smaller size classes. When Daphnia was less abundant, pumpkinseed shifted to smaller cladocerans and copepods, as shown for other planktivores (Roseman et al., 1996; Gliwicz et al., 2004; Scheuerell et al., 2005). This is not surprising, given the extremely high abundances of small-sized cladocerans and cyclopoid copepods in Lake Vela (see Fig. 4), which reduce the predator's perception of larger prey below a certain density threshold (see Gliwicz, 2001; Gliwicz et al., 2004).

Pumpkinseed seems thus to be able to shift dynamically food resource use (benthos, large and small zooplankton) without compromising its growth rates or reproductive success in Lake Vela, thus confirming flexible foraging behaviour (vide Roseman et al., 1996; Scheuerell et al., 2005). Note that not all fish species remain unaffected by the collapse of Daphnia in the lake (e.g., Prout et al., 1990; Roseman et al., 1996). Pumpkinseed takes profit from the lake's high productivity and shallowness, which provides simultaneous access to benthic and planktonic prey. In this way, it does not seem to depend much on a single prey item or food source, unlike more specialized planktivores.

After the collapse of D. longispina and the clear water phase in May, low Daphnia densities were observed and no recovery was observed throughout the summer, as typically observed in other temperate lakes and attributable to fish-induced mortality (e.g., Boersma et al., 1996). However, virtually no Daphnia were found from June to

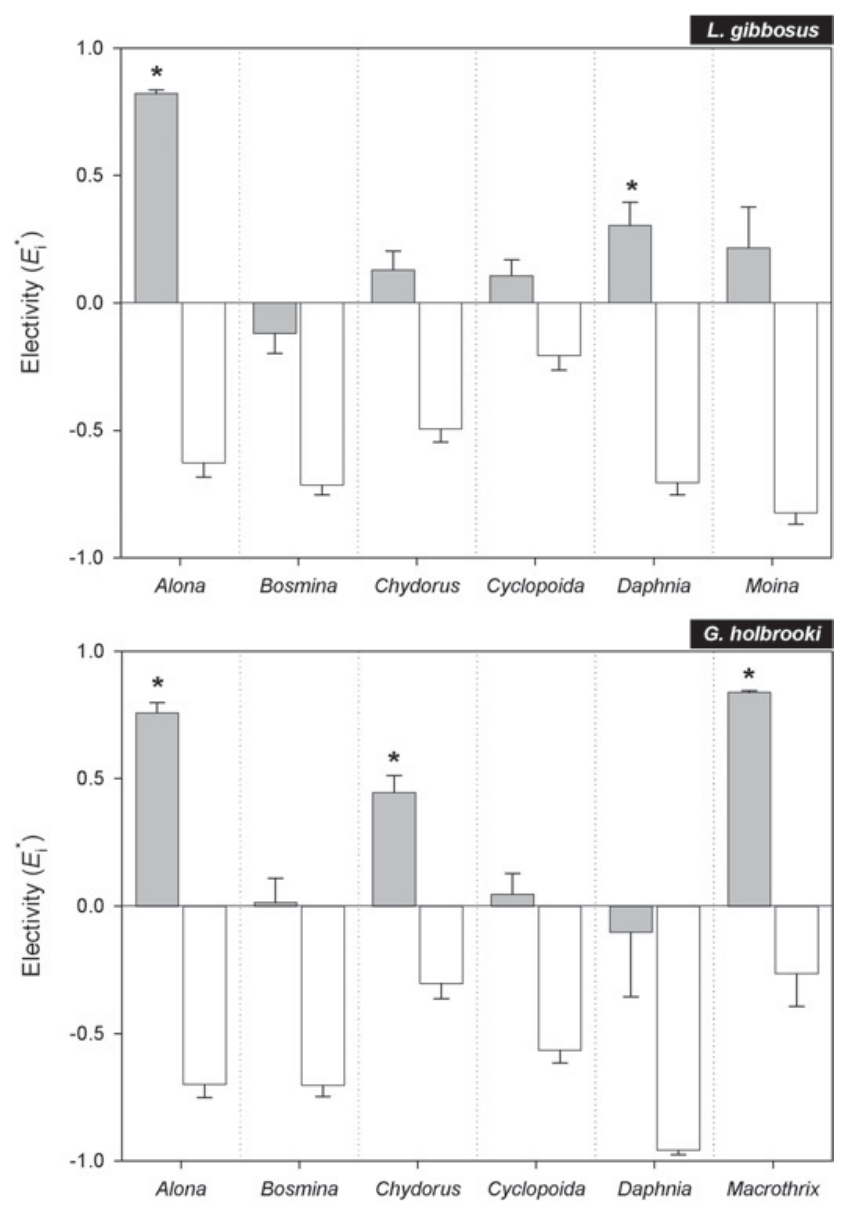

Fig. 5. Electivity $\left(E_{i}^{*}\right)$ values (means $\pm \mathrm{SE}$ ) for the major prey categories in pumpkinseed (top) and mosquitofish (bottom), averaged for the entire sampling period (April-January). Bars represent the selectivity index when computed with (white) and without (grey) accounting for guts where prey category was absent $\left(E_{i}^{*}=-1\right)$. Significant deviations from 0 are marked with * (sign test, $P \leq 0.05)$.

October in mosquitofish, pumpkinseed or bass stomachs from Lake Vela, even though they were still observed in the lake in June and July. This result suggests that other factors besides predation also contribute to the suppression of Daphnia during the summer and autumn (e.g., cyanobacterial blooms). Still, our findings show that the combined effects of mosquitofish (littoral) and pumpkinseed (littoral and open water) make Lake Vela a hostile place for zooplankters to live.

Acknowledgements. Acknowledgements are due to José Vingada (University of Minho, Portugal) for supplying the fishing gear apparatuses and for providing help during fieldwork. We are also thankful to Francisca F. Gouveia for her laborious collaboration in the measurement and dissection of the fish. Bruno B. Castro was supported by a PhD grant (ref. SFRH/BD/6417/2001) from Fundação para a Ciência e a Tecnologia (Portugal). Bruno B. Castro is presently hired under the programme Ciência 2008 (FCT, Portugal), co-funded by the Human Potential Operational Programme (National Strategic Reference 
Framework 2007-2013) and European Social Fund (EU). We also thank two anonymous referees for their contribution in the improvement of the manuscript.

\section{References}

Abrantes N., Antunes S.C., Pereira M.J. and Gonçalves F., 2006. Seasonal succession of cladocerans and phytoplankton and their interactions in a shallow eutrophic lake (Lake Vela, Portugal). Acta Oecol., 29, 54-64.

Alcaraz C. and Garcia-Berthou E., 2006. Food of an endangered cyprinodont (Aphanius iberus): ontogenetic diet shift and prey electivity. Environ. Biol. Fish, 78, 193-207.

Almaça C., 1995. Fish species and varieties introduced into Portuguese inland waters, Museu Nacional de História Natural, Lisbon.

Amundsen P.A., Gabler H.M. and Staldvik F.J., 1996. A new approach to graphical analysis of feeding strategy from stomach contents data - modification of the Costello (1990) method. J. Fish Biol., 48, 607-614.

Antunes S.C., Abrantes N. and Gonçalves F., 2003. Seasonal variation of the abiotic parameters and the cladoceran assemblage of Lake Vela: comparison with previous studies. Ann. Limnol. - Int. J. Limnol., 39, 255-264.

Beklioglu M., Romo S., Kagalou I., Quintana X. and Bécares E., 2007. State of the art in the functioning of shallow Mediterranean lakes: workshop conclusions. Hydrobiologia, 584, 317-326.

Blanco S., Romo S., Villena M.J. and Martínez S., 2003. Fish communities and food web interactions in some shallow Mediterranean lakes. Hydrobiologia, 506, 473-480.

Blanco S., Romo S. and Villena M.J., 2004. Experimental study on the diet of mosquitofish (Gambusia holbrooki) under different ecological conditions in a shallow lake. Int. Rev. Hydrobiol., 89, 250-262.

Boersma M., Van Tongeren O.F.R. and Mooij W.M., 1996. Seasonal patterns in the mortality of Daphnia species in a shallow lake. Can. J. Fish Aquat. Sci., 53, 18-28.

Borcard D., Legendre P. and Drapeau P., 1992. Partialling out the spatial component of ecological variation. Ecology, 73, 1045-1055.

Cabral J.A. and Marques J.C., 1999. Life history, population dynamics and production of eastern mosquitofish, Gambusia holbrooki (Pisces, Poeciliidae), in rice fields of the lower Mondego River valley, western Portugal. Acta Oecol., 20, 607-620.

Cabral J.A., Mieiro C.L. and Marques J.C., 1998. Environmental and biological factors influence the relationship between a predator fish, Gambusia holbrooki, and its main prey in rice fields of the lower Mondego River valley (Portugal). Hydrobiologia, 382, 41-51.

Cambray J.A., 2003. Impact on indigenous species biodiversity caused by the globalisation of alien recreational freshwater fisheries. Hydrobiologia, 500, 217-230.

Castro B.B. and Gonçalves F., 2007. Seasonal dynamics of the crustacean zooplankton of a shallow eutrophic lake from the Mediterranean region. Fundam. Appl. Limnol. - Arch. Hydrobiol., 169, 189-202.

Castro B.B., Marques S.M. and Gonçalves F., 2007. Habitat selection and diel distribution of the crustacean zooplankton from a shallow Mediterranean lake during the turbid and clear water phases. Freshw. Biol., 52, 421-433.

Eklöv P. and Van Kooten T., 2001. Facilitation among piscivorous predators: effects of prey habitat use. Ecology, 82, 2486-2494.

Fernández-Delgado C., 1989. Life-history patterns of the mosquito-fish, Gambusia affinis, in the estuary of the Guadalquivir River of south-west Spain. Freshw. Biol., 22, 395-404.

García-Berthou E., 1999. Food of introduced mosquitofish: ontogenic diet shift and prey selection. J. Fish Biol., 55, 135-147.

García-Berthou E. and Moreno-Amich R., 2000. Food of introduced pumpkinseed sunfish: ontogenic diet shift and seasonal variation. J. Fish Biol., 57, 29-40.

Gliwicz Z.M., 2001. Species-specific population-density thresholds in cladocerans? Hydrobiologia, 442, 291-300.

Gliwicz Z.M., Jawinski A. and Pawlowicz M., 2004. Cladoceran densities, day-to-day variability in food selection by smelt, and the birth-rate-compensation hypothesis. Hydrobiologia, $526,171-186$.

Godinho F.N., Ferreira M.T. and Cortes R.V., 1997. The environmental basis of diet variation in pumpkinseed sunfish, Lepomis gibbosus, and largemouth bass, Micropterus salmoides, along an Iberian river basin. Environ. Biol. Fish, 50, 105-115.

Hansson L.A., Nicolle A., Brodersen J., Romare P., Nilsson P.A., Brönmark C. and Skov C., 2007. Consequences of fish predation, migration, and juvenile ontogeny on zooplankton spring dynamics. Limnol. Oceanogr., 52, 696-706.

Hurlbert S.H., Zedler J. and Fairbanks D., 1972. Ecosystem alteration by mosquitofish (Gambusia affinis) predation. Science, 175, 639-641.

Hyslop E.J., 1980. Stomach contents analysis - a review of methods and their application. J. Fish Biol., 17, 411-429.

Jeppesen E., Jensen J.P., Søndergaard M., Lauridsen T.L., Pedersen L.J. and Jensen L., 1997. Top-down control in freshwater lakes: the role of nutrient state, submerged macrophytes and water depth. Hydrobiologia, 342/343, 151-164.

Jeppesen E., Meerhoff M., Jacobsen B.A., Hansen R.S., Søndergaard M., Jensen J.P., Lauridsen T.L., Mazzeo N. and Branco C.W.C., 2007. Restoration of shallow lakes by nutrient control and biomanipulation - the successful strategy varies with lake size and climate. Hydrobiologia, 581, 269-285.

Jeppesen E., Meerhoff M., Holmgren K., González-Bergonzoni I., Teixeira de Mello F., Declerck S.A.J., De Meester L., Søndergaard M., Lauridsen T.L., Bjerring R., CondePorcuna J.M., Mazzeo N., Iglesias C., Reizenstein M., Malmquist H.J., Liu Z., Balayla D. and Lazzaro X., 2010. Impacts of climate warming on lake fish community structure and potential effects on ecosystem function. Hydrobiologia, 646, 73-90.

Lechowicz M.J., 1982. The sampling characteristics of electivity indices. Oecologia, 52, 22-30.

Maazouzi C., Médoc V., Pihan J.C. and Masson G., 2010. Size-related dietary changes observed in young-of-the-year pumpkinseed (Lepomis gibbosus): stomach contents and fatty acid analyses. Aquat. Ecol., 45, 23-33.

Margaritora F.G., Ferrara O. and Vagaggini D., 2001. Predatory impact of the mosquitofish (Gambusia holbrooki Girard) 
on zooplanktonic populations in a pond at Tenuta di Castelporziano (Rome, Central Italy). J. Limnol., 60, 189-193.

Matveev V., Matveeva L. and Jones G.J., 2000. Relative impacts of Daphnia grazing and direct stimulation by fish on phytoplankton abundance in mesocosm communities. Freshw. Biol., 44, 375-385.

Moss B., Stephen D., Balayla D.M., Becares E., Collings S.E., Fernández-Aláez C., Fernández-Aláez M., Ferriol C., Garcia P., Goma J., Gyllstrom M., Hansson L.A., Hietala J., Kairesalo T., Miracle M.R., Romo S., Rueda J., Russell V., Stahl-Delbanco A., Svensson M., Vakkilainen K., Valentin M., Van de Bund W.J., van Donk E., Vicente E. and Villena M.J., 2004. Continental-scale patterns of nutrient and fish effects on shallow lakes: synthesis of a pan-European mesocosm experiment. Freshw. Biol., 49, 1633-1649.

Nagdali S.S. and Gupta P.K., 2002. Impact of mass mortality of a mosquito fish, Gambusia affinis on the ecology of a fresh water eutrophic lake (Lake Naini Tal, India). Hydrobiologia, 468, 45-52.

Økland R.H. and Eilersten O., 1994. Canonical correspondence analysis with variation partitioning: some comments and an application. J. Veg. Sci., 5, 117-126.

Post D.M., Carpenter S.R., Christensen D.L., Cottingham K.L., Kitchell J.F., Schindler D.E. and Hodgson J.R., 1997. Seasonal effects of variable recruitment of a dominant piscivore on pelagic food web structure. Limnol. Oceanogr., 42, 722-729.

Prout M.W., Mills E.L. and Forney J.L., 1990. Diet, growth, and potential competitive interactions between age- 0 white perch and yellow perch in Oneida Lake, New York. Trans. Am. Fish Soc., 119, 966-975.

Robinson B.W., Wilson D.S., Margosian A.S. and Lotito P.T., 1993. Ecological and morphological differentiation of pumpkinseed sunfish in lakes without bluegill sunfish. Evol. Ecol., 7, 451-464.

Romare P. and Hansson L.A., 2003. A behavioral cascade: top-predator induced behavioral shifts in planktivorous fish and zooplankton. Limnol. Oceanogr., 48, 1956-1964.

Romare P., Bergman E. and Hansson L.A., 1999. The impact of larval and juvenile fish on zooplankton and algal dynamics. Limnol. Oceanogr., 44, 1655-1666.
Romo S., Miracle M.R., Villena M.J., Rueda J., Ferriol C. and Vicente E., 2004. Mesocosm experiments on nutrient and fish effects on shallow lake food webs in a Mediterranean climate. Freshw. Biol., 49, 1593-1607.

Roseman E.F., Mills E.L., Forney J.L. and Rudstam L.G., 1996. Evaluation of competition between age-0 yellow perch (Perca flavescens) and gizzard shad (Dorosoma cepedianum) in Oneida Lake, New York. Can. J. Fish Aquat. Sci., 53, 865-874.

Ruesink J.L., 2005. Global analysis of factors affecting the outcome of freshwater fish introductions. Conserv. Biol., 19, 1883-1893.

Scheffer M., 1998. Ecology of Shallow Lakes, Chapman and Hall, London.

Scheuerell J.M., Schindler D.E., Scheuerell M.D., Fresh K.L., Sibley T.H., Litt A.H. and Shepherd J.H., 2005. Temporal dynamics in foraging behavior of a pelagic predator. Can. J. Fish Aquat. Sci., 62, 2494-2501.

Tátrai I., Mátyás K., Korponai J., Paulovits G., Pomogyi P. and Héri J., 2003. Regulation of plankton by omnivore cyprinids in a shallow lake in the Kis-Balaton Reservoir System. Hydrobiologia, 504, 241-250.

Teixeira de Mello F., Meerhoff M., Pekcan-Hekim Z. and Jeppesen E., 2009. Substantial differences in littoral fish community structure and dynamics in subtropical and temperate shallow lakes. Freshw. Biol., 54, 1202-1215.

ter Braak C.J.F., 1986. Canonical correspondence analysis: a new eigenvector technique for multivariate direct gradient analysis. Ecology, 67, 1167-1179.

ter Braak C.J.F., 1988. Partial canonical correspondence analysis. In: Bock H.H. (ed.), Classification and Related Methods of Data Analysis, North-Holland, Amsterdam, 551-558.

Williams A.E. and Moss B., 2003. Effects of different fish species and biomass on plankton interactions in a shallow lake. Hydrobiologia, 491, 331-346.

Wolfram-Wais A., Wolfram G., Auer G., Mikschi E. and Hain A., 1999. Feeding habits of two introduced fish species (Lepomis gibbosus, Pseudorasbora parva) in Neusiedler See (Austria), with special reference to chironomid larvae (Diptera: Chironomidae). Hydrobiologia, 408/409, 123-129. 


\section{Appendix}

Table A1. Planktivory in YOY largemouth bass in Lake Vela from April to January. The contribution of zooplankton to total diet is shown as mean abundance relative to total stomach contents $(\% \mathrm{~A})$ and percent occurrence $(\% \mathrm{O})$. Results are presented as percent composition in terms of numerical abundance. ND stands for no data.

\begin{tabular}{|c|c|c|c|c|c|c|c|}
\hline \multirow[b]{2}{*}{ Month } & \multirow{2}{*}{\multicolumn{2}{|c|}{ Contribution of zooplankton to total diet }} & \multicolumn{5}{|c|}{ Mean percent composition within zooplankton component } \\
\hline & & & Daphnia & Bosmina & Chydorus & Other Cladocera & Copepoda \\
\hline & $\% \mathrm{O}$ & $\% \mathrm{~A}$ & & & & & \\
\hline Apr. & - & - & & & & & \\
\hline May & 100 & 99 & 8 & 18 & 55 & 1 & 18 \\
\hline Jun. & 75 & 61 & 10 & 8 & 0 & 1 & 81 \\
\hline Jul. & ND & ND & & & & & \\
\hline Aug. & 0 & 0 & - & - & - & - & - \\
\hline Sep. & 0 & 0 & - & - & - & - & - \\
\hline Oct. & ND & ND & & & & & \\
\hline Jan. & ND & ND & & & & & \\
\hline
\end{tabular}

Table A2. Planktivory in pumpkinseed sunfish in Lake Vela from April to January. The contribution of zooplankton to total diet is shown as mean abundance relative to total stomach contents $(\% \mathrm{~A})$ and percent occurrence $(\% \mathrm{O})$. Results are presented as percent composition in terms of numerical abundance. ND stands for no data.

\begin{tabular}{|c|c|c|c|c|c|c|c|}
\hline \multirow[b]{2}{*}{ Month } & \multirow{2}{*}{\multicolumn{2}{|c|}{ Contribution of zooplankton to total diet }} & \multicolumn{5}{|c|}{ Mean percent composition within zooplankton component } \\
\hline & & & Daphnia & Bosmina & Chydorus & Other Cladocera & Copepoda \\
\hline$<60 \mathrm{~mm}$ & $\% \mathrm{O}$ & $\% \mathrm{~A}$ & & & & & \\
\hline Apr. & 100 & 63 & 0 & 0 & 9 & 23 & 68 \\
\hline May & 100 & 79 & 0 & 0 & 34 & 58 & 8 \\
\hline Jun. & 100 & 73 & 0 & 56 & 8 & 15 & 21 \\
\hline Jul. & 100 & 79 & 1 & 2 & 38 & 28 & 31 \\
\hline Aug. & 29 & 15 & 0 & 15 & 0 & 56 & 29 \\
\hline Sep. & 100 & 70 & 0 & 48 & 0 & 18 & 34 \\
\hline Oct. & 100 & 96 & 0 & 93 & 2 & 1 & 4 \\
\hline Jan. & 100 & 90 & 14 & 2 & 22 & 1 & 61 \\
\hline $60-100 \mathrm{~mm}$ & $\% \mathrm{O}$ & $\% \mathrm{~A}$ & & & & & \\
\hline Apr. & 100 & 36 & 79 & 0 & 0 & 1 & 20 \\
\hline May & 100 & 49 & 0 & 1 & 30 & 40 & 29 \\
\hline Jun. & 80 & 14 & 0 & 42 & 8 & 16 & 34 \\
\hline Jul. & 94 & 34 & 0 & 1 & 21 & 31 & 47 \\
\hline Aug. & 7 & $<0.1$ & 0 & 0 & 100 & 0 & 0 \\
\hline Sep. & 80 & 34 & 0 & 16 & 0 & 14 & 70 \\
\hline Oct. & 0 & 0 & - & - & - & - & - \\
\hline Jan. & ND & ND & & & & & \\
\hline$>100 \mathrm{~mm}$ & $\% \mathrm{O}$ & $\% \mathrm{~A}$ & & & & & \\
\hline Apr. & 100 & 31 & 71 & 0 & 0 & 2 & 27 \\
\hline May & 71 & 8 & 2 & 0 & 26 & 40 & 32 \\
\hline Jun. & 67 & 10 & 0 & 0 & 50 & 0 & 50 \\
\hline Jul. & ND & ND & & & & & \\
\hline Aug. & ND & ND & & & & & \\
\hline Sep. & ND & ND & & & & & \\
\hline Oct. & ND & ND & & & & & \\
\hline Jan. & ND & ND & & & & & \\
\hline
\end{tabular}


Table A3. Planktivory in mosquitofish in Lake Vela from April to January. The contribution of zooplankton to total diet is shown as mean abundance relative to total stomach contents $(\% \mathrm{~A})$ and percent occurrence $(\% \mathrm{O})$. Results are presented as percent composition in terms of numerical abundance. ND stands for no data.

\begin{tabular}{|c|c|c|c|c|c|c|c|c|}
\hline \multirow[b]{2}{*}{ Month } & \multirow{2}{*}{\multicolumn{2}{|c|}{ Contribution of zooplankton to total diet }} & \multicolumn{6}{|c|}{ Mean percent composition within zooplankton component } \\
\hline & & & Daphnia & Bosmina & Chydorus & Macrothrix & Other Cladocera & Copepoda \\
\hline$<20 \mathrm{~mm}$ & $\% \mathrm{O}$ & $\% \mathrm{~A}$ & & & & & & \\
\hline Apr. & 100 & 85 & 2 & 0 & 39 & 0 & 1 & 58 \\
\hline May & 100 & 92 & 0 & 0 & 79 & 0 & 15 & 6 \\
\hline Jun. & 100 & 100 & 0 & 83 & 14 & 0 & 0 & 3 \\
\hline Jul. & 100 & 84 & 0 & 16 & 41 & 0 & 14 & 29 \\
\hline Aug. & 22 & 15 & 0 & 0 & 0 & 100 & 0 & 0 \\
\hline Sep. & 67 & 37 & 0 & 16 & 7 & 66 & 3 & 8 \\
\hline Oct. & 83 & 79 & 0 & 36 & 32 & 3 & 0 & 29 \\
\hline Jan. & 75 & 35 & 0 & 0 & 78 & 0 & 0 & 22 \\
\hline $20-30 \mathrm{~mm}$ & $\% \mathrm{O}$ & $\% \mathrm{~A}$ & & & & & & \\
\hline Apr. & 83 & 70 & 4 & 0 & 11 & 0 & 10 & 75 \\
\hline May & 100 & 84 & 7 & 0 & 66 & 0 & 1 & 26 \\
\hline Jun. & 92 & 92 & 0 & 97 & 0 & 0 & 0 & 2 \\
\hline Jul. & 100 & 97 & 0 & 1 & 91 & 0 & 1 & 6 \\
\hline Aug. & 0 & 0 & - & - & - & - & - & - \\
\hline Sep. & 93 & 80 & 0 & 10 & 0 & 85 & 2 & 3 \\
\hline Oct. & 100 & 100 & 0 & 93 & 5 & 0 & 0 & 1 \\
\hline Jan. & 100 & 87 & 0 & 0 & 72 & 0 & 9 & 19 \\
\hline$>30 \mathrm{~mm}$ & $\% \mathrm{O}$ & $\% \mathrm{~A}$ & & & & & & \\
\hline Apr. & 78 & 66 & 0 & 0 & 1 & 0 & 0 & 99 \\
\hline May & 86 & 72 & 0 & 0 & 85 & 0 & 15 & 1 \\
\hline Jun. & 67 & 55 & 0 & 97 & 0 & 0 & 0 & 3 \\
\hline Jul. & 88 & 77 & 0 & 1 & 74 & 0 & 20 & 4 \\
\hline Aug. & 0 & 0 & - & - & - & - & - & - \\
\hline Sep. & 50 & 48 & 0 & 97 & 0 & 0 & 0 & 3 \\
\hline Oct. & 100 & 99 & 0 & 99 & 1 & 0 & 0 & 0 \\
\hline Jan. & 100 & 58 & 0 & 0 & 29 & 0 & 0 & 71 \\
\hline
\end{tabular}

